CHARTER AND UNCLOS 1982
: Enny Narwati
DOI




\title{
THE PRINCIPLE OF NEUTRALITY AT SEA AFTER UN CHARTER AND UNCLOS 1982*
}

\author{
Enny Narwati** \\ International Law Departement, Faculty of Law, Universitas Airlangga \\ Dharmawangsa Dalam Selatan, Surabaya, East Java, 60286
}

\begin{abstract}
The purpose of this paper is to analyze an implementation of neutrality principles in time of naval warfare. It because the law of neutrality has not progressed since Hague Convention 1907. Indeed, the UN Charter and UNCLOS 1982 set up significant developments on international law. On the other hand, there still found a lack of rules available in particular area, therefore international community provide SRM 1994. The SRM 1994 created based on the Hague Convention 1907, UN Charter, UNCLOS 1982, and other international treaties. To conclude, that the law of neutrality at sea should respected the sovereignty of neutral countries.
\end{abstract}

Keywords: neutrality at sea, UN Charter, UNCLOS 1982.

\section{Intisari}

Tulisan ini bertujuan melakukan analisis mendalam mengenai pelaksanaan netralitas di laut. Hal ini dikarenakan pengaturan hukum netralitas di laut tidak mengalami perkembangan sejak Konvensi Den Haag 1907. Di sisi lain, dunia internasional mengalami perkembangan penting, terutama dengan adanya Piagam PBB dan disahkannya UNCLOS 1982. Guna mengisi kekosongan hukum, maka dibuatlah San Remo Manual 1994 yang berpedoman pada Konvensi Den Haag 1907, Piagam PBB, UNCLOS 1982, perjanjian internasional lainnya dan hukum kebiasaan internasional. Berdasarkan analisis yang dilakukan akan ditemukan solusi mengenai pengaturan netralitas di laut yang lebih memperhatikan kepentingan dan kedaulatan negara netral.

Kata Kunci: netralitas di laut, Piagam PBB, UNCLOS 1982.

\section{Pokok Muatan}

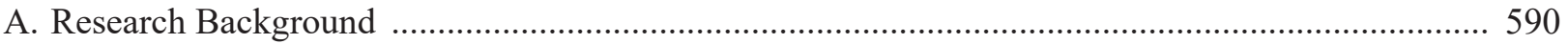

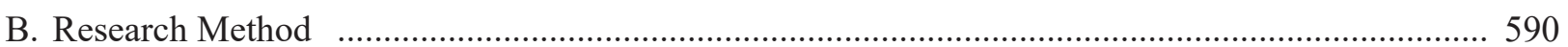

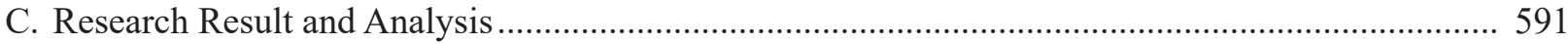

1. The Development of the Principle of Neutrality ...................................................................... 591

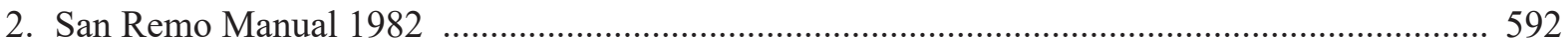

3. The Principle of Neutrality at Sea and UN Charter …................................................................ 593

4. The Principle of Neutrality at Sea According to San Remo Manual 1994 ................................. 595

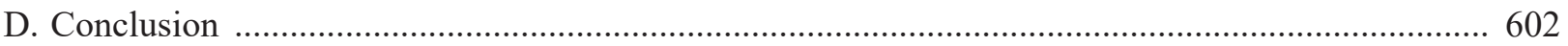

* This paper is a result of Doctoral Dissertation Research, funded by DP2M Ditjen Dikti of 2016.

** Correspondence address: enny wasono@yahoo.com. 


\section{A. Research Background}

The regulation of the principle of neutrality at the time of armed conflict is now experiencing uncertainty, particularly after the UN Charter and United Nations Convention on the Law of the Sea 1982 (UNCLOS 1982). The first regulation regarding the principle of neutrality at the sea is Declaration Respecting Maritime Law, Paris, signed on 30 March 1856 and entered into force on 16 April 1856. This declaration is prepared for clarifying the relationship between neutral state and conflicted parties, and governing 4 terms, which is: (a) It is prohibited to use merchant ship during the warfare; (b) neutral ship is allowed to carry enemy's goods; (c) neutral goods is not allowed to be captured; and (d) the blockade has to be effective; ${ }^{1}$ the regulation of neutrality can be further found in The Hague Convention XII 1907 regarding Rights and Duties of Neutral Powers in Naval War at the Sea. ${ }^{2}$ In 1928, by the initiative of American Institute of International Law, was held a conference which discussed about the neutrality at the sea, and it produced Havana Convention 1928. ${ }^{3}$ Such conference was attended by 8 states and signed by 13 states. However, the convention has never been entered into force effectively since it was not ratified by none of the states. ${ }^{4}$

The development of international situation triggers international society to make a change or adapting the provisions of the law of armed conflict at the sea, including the principle of neutrality. Such developments occurred due to the existence of Chapter VII of The UN Charter concerning Action with Respect to Threats to the Peace, Breaches of the Peace, and Acts of Aggression. With regards to the provisions contained under Chapter VII, therefore,
Security Council (SC) can force the member states for participating in humanitarian invention and putting aside rights and obligation member states as neutral states. Besides the UN Charter. UNCLOS 1982 has brought changes on the area of conflict operation of naval warfare. By the change of sea zonation, it also affects to the implementation of the principle of neutrality at sea.

The provision of humanitarian law at the sea concerning the principle of neutrality, particularly The Hague Convention XIII 1907 cannot accommodate such development, thus there is legal vacuum in the regulation of the principle of neutrality at sea. In order to fill the legal vacuum, International Institute of Humanitarian Law (IIHL) discusses about the necessary of reforming the law of armed conflict at sea (not only about the principle of neutrality). ${ }^{5}$ After several meetings, it produced a guideline called San Remo Manual on International Law Applicable to Armed Conflict at Sea, June 1994 (hereinafter San Remo Manual 1994), adopted in June 1994, in San Remo, Italy. San Remo Manual 1994 tried to harmonize with the provisions that contained under UN Charter and UNCLOS 1982, in particular about the implantation of the principle of neutrality and operation area as well as the use of method and means of naval warfare.

\section{B. Research Method}

Legal research is a process for finding either the rule of law or doctrines of law in order to answer the legal issue being researched. ${ }^{6}$ This research is a normative research. The approach that has been used in this research is statute approach, conceptual approach and historical approach. Statute approach is conducted by way of analyzing

International Committee of The Red Cross, "Declaration Respecting Maritime Law Paris, 16 April 1856", https://ihl-databases.icrc.org/ihl/ WebART/105-10001? OpenDocument, accessed 11 December 2016.

Convention (XIII) concerning the Rights and Duties of Neutral Powers in Naval War, The Hague, 18 October 1907,36 Stat. 2415 , T.S. No. 545 (entered into force 26 January 1910).

Convention on Maritime Neutrality. Havana, 20 February 1928.

4 International Committee of The Red Cross, "Treaties, State Parties and Commentaries", https://ihl-databases.icrc.org/ihl/WebART/10510001? OpenDocument, accessed 31 August 2016.

Salah El-Din Amer, San Remo Manual on International Law Applicable to Armed Conflicts at Sea, Adopted in June 1994, Explanation, dalam Louise Doswald-Back, 1995, San Remo Manual on International Law Applicable to Armed Conflicts at Sea / prepared by international lawyer and naval experts convened by International Institute of Humanitarian Law, Cambridge University Press, Great Britain, p. 61.

6 Peter Mahmud Marzuki, 2005, Penelitian Hukum, Kencana Prenada Media Group, Jakarta, p. 35. 
the provision of international law, particularly The Hague Conventions 1907 concerning the Principle of Neutrality, UNCLOS 1982, San Remo Manual 1994 and other related international conventions. The conceptual approach elaborates about the doctrines and views from leading law scholars, legal concepts, and principles in relation with the issued being researched. Legal concept is not only found under the existing international law regulation, either in written or unwritten. Furthermore, historical approach is conducted in this research since the law of armed conflict currently cannot be separated from the previous regulations.

This legal research used 2 (two) types of legal materials, that is primary law and secondary law. Primary law is a legal material that is based on or produced by an authority body, in the form of official documents such as international convention, statute or other legal provision related to the researched issue. Secondary law is legal material that is not official document, which is found in literature study, such as research either textbook, journals, or other information.

The research is conducted in two stages, that is collecting legal materials and analyzing the legal material and bibliographical research. Then the legal materials were identified and put it in inventory, then analyzing it.

\section{Research Result and Analysis \\ 1. The Development of the Principle of Neutrality}

The principle of neutrality governs regarding the legal relationship between states that is involved in armed conflict and and the state which is not participated in an armed conflict, called as neutral states. The Principle of Neutrality aims to localize the war, limit the conduct of war, either on land or at sea and reducing the effects of warfare for international trade. ${ }^{7}$ In the past, particularly before the Second World War, the principle of neutrality was obviously important for distinguishing between the warfare and peace, since a war should be declared. When a state declared war, therefore the third state that was not involved in such conflict, would declare its neutral status. However, after the Second World War, due to The Geneva Convention 1949, the states was no longer using war declaration for commencing the war, and International Humanitarian Law would automatically be applicable in an armed conflict, even if the warfare was not claimed by one of the parties. ${ }^{8}$ In this situation, it might intervene the principle of neutrality, since there are no significant differences from peaceful situation to the warfare or armed conflict. The states that is not involved in the war never declared themselves as neutral states.

According to, Kalshoven, the neutrality has two meanings, first, it means not participating in a conflict and have no rights. ${ }^{9}$ Not participating in a conflict means there is an obligation for avoiding the involvement in an armed conflict. Neutral states should avoid the measures which related to such conflict without putting aside the rights of selfdefense and protecting the legal interest based on International Law. Not showing partiality reflects that there is an obligation of neutral states for treating the conflicting parties equally. The obligation of each conflicting parties towards the neutral states is that respecting the neutral state and not breaching such neutrality.

Based on Haryomataram, the considerations either legal or ratio which support the neutral states is that: (a) the neutrality is able to localize the warfare; (b) the neutrality provides the possibilities for states for staying away from the warfare; and (c) governing the legal relationship between the conflicting parties and the neutral state. ${ }^{10}$

The regulation of the principle of neutrality at

\footnotetext{
A.R. Thomas and James C. Duncan (Editors), 1999, Annotated Supplement to The Commander's Handbook on the Law of Naval Operations, Newport RI, Newport, p. 365.

Article 2 of the Geneva Convention 1949

Kalshoven, 2007, Reflections on the Law of War :Collected Essays, Martinus Nijhoff Publisher, London, p. 1033.

Haryomataram, 2005, Pengantar Hukum Humaniter, RajaGrafindo Persada, Jakarta, , pp. 222-223.
} 
sea can be found under The Hague Convention XIII 1907. However, the implementation of the principle of neutrality experienced development due to the existence of UN Charter which obliges the member states to obey the decisions of The United Nations Security Council and putting aside the principle of neutrality which applicable during this time and also the existence of UNCLOS 1982. ${ }^{11}$ Such development was then regulated under San Remo Manual 1994.

\section{San Remo Manual 1982}

\section{a. The Standing of San Remo Manual 1982 as a Source of International Law}

As a manual, San Remo Manual 1994 has a unique form. Besides as a legal principles and legal scholar opinion, most likely San Remo Manual 1994 can be a customary international law. The paragraphs under San Remo Manual 1994 came from customary international law, international convention, states practice and some brand new provisions. Most of the provision of San Remo Manual 1994 is a re-regulation of the existence provision of The Hague Convention 1907, The Geneva Convention 1949, and Additional Protocol I 1977. The first two conventions has been applied universally and became customary international law, meanwhile Additional Protocol I 1977 is only bound for states who have ratified it. Thus, the norms under San Reo Manual 1944 derived from such international treaty also has a status as customary international law. Whereas, the regulations concerning with the new issues in San Remo Manual 1994 has not fulfilled the requirement as a customary international law, thus it needs efforts and times for becoming customary international law.

As general legal principles, San Remo Manual 1994 is an implementation of general legal principles, particularly legal principles of International Humanitarian Law. The general legal principles are reflected under the basic of the principle of military necessity lied down under paragraph $38,{ }^{12}$ the basic rule from the principle of distinction that is found under Paragraph $39,{ }^{13}$ as well as the basic rule of the principle of humanity reflected under Paragraph 42 asserts that it is prohibited using method and means of warfare which results to severe loss, or indiscriminate attack. ${ }^{14}$ Such paragraphs constitute the basic rules of the principle of proportionality, in order to balance the implementation of others principles.

According to experts' opinion, San Remo Manual 1994 was made by the experts in International Law as well as other leading legal scholars, which was sponsored by International Institute of Humanitarian Law (IIHL) based in Geneva and got fully supported from International Committee of the Red Cross (ICRC). There are 56 experts coming from across the countries, ${ }^{15}$ which consist of various professions, from academics, member of naval force, ICRC, IIHL, Ministry of Foreign Affair, Department of Defense and judge. ${ }^{16}$ Therefore, it can be said that the members of San Remo Manual 1994 is a crystallization of leading experts and can be categorized as an additional source of International Law.

Paragraph 38 of San Remo Manual 1994: "In any armed conflict the right of the parties to the conflict to choose methods or means of warfare is not unlimited."

13 Paragraf 39 San Remo Manual 1994: "Parties to the conflict shall at all times distinguish between civilians or other protected persons and combatants and between civilian or exempt objects and military objectives."

14 Paragraph 42 of San Remo Manual 1994.

15 Such experts are from: Italy, France, Egypt, England, Sweden, Canada, Switzerland, Singapore, Norway, the Netherlands, Israel, The United States of America, China, Germany, Argentina, Belgium, Russia, Austria, Japan, Iran, Australia, and Croatia.

16 Annex San Remo Manual on International Law Applicable to Armed Conflicts at Sea 1994. 
Based on discussion above, nowadays, the standing of San Remo Manual 1994 is as experts' opinions that contains the general principles of law and currently is in a process to be a customary international law.

\section{b. The Importance of San Remo Manual 1994}

Even though the armed conflict at sea is not as often as the conflict on land, however, some conflicts occurred shows that there is a necessity on legal certainty in armed conflict at sea. Some issues show the importance of San Remo Manual 1994 in International Law, particularly in International Humanitarian Law is that:

As a guidance in governing the conduct of states involved in an armed conflict. San Remo Manual 1994 is a comprehensive instrument of International Law which regulates the conduct of armed conflict at sea. San Remo Manual is a compilation rules of International Humanitarian Law start from The Hague Convention 1907 to the enactment of UNCLOS 1982. The existence of San Remo 1994 is obviously important in fulfilling the legal vacuum of regulating the conduct of armed conflict at sea.

As a guideline, San Remo Manual 1994 provides a discretion for states to adjust with their national laws and prioritizing the states sovereignty. The advantage of San Remo Manual 1994 is that it has a nature of not binding. By the nature of non-binding, San Remo Manual 1994 is more flexible in adjusting with each national laws. By providing the discretion for the states to produce their own rules thus the states does not feel to be limited by their sovereignty in applying San Remo Manual 1994.

\section{The Principle of Neutrality at Sea and UN Charter}

After UN Charter, particularly after the end of Cold War, the understanding of neutrality became inadequate. It was due to the rule of International Law with regards to the Principle of Neutrality was no longer appropriate with the existing development. Based on UN Charter, the states are not allowed to use armed violence in dispute settlement, ${ }^{17}$ thus if there is a reason for protecting the interest of third party or neutral states is no longer relevant.

UN Charter obliges the member states for settling the disputes between them by peaceful means. Particularly, it is not allowed to use threat or military armed forces. If the UN Security Council enacts that by the existence of threats or there is a violation of the world peace or violation of an aggression based on Chapter VII of UN Charter, thus the UN Security Council can decide the measures of enforcement, including by way of either military armed force ${ }^{18}$ or non-military, ${ }^{19}$ which aims for keeping or restoring international peace and security. When the Security Council needs member states' participation, so the member states are obliged to support the decision of Security Council or the Security Council is able to appoint certain states for conducting law enforcement measure against the existing violation..$^{20}$ Particularly, the member states are not allowed to provide assistance in any form to the states who breach international law. However, the state is allowed to send humanitarian assistance, after the approval of the Security Council.

Such obligation is governed under the UN Charter and has a higher force of law than the applicable principle of neutrality at sea. ${ }^{21}$ When the Security Council has implemented its power under Chapter VII of the Charter, all the member states have to agree and carry out the decision of the Security Council. The main reason of the involvement of the

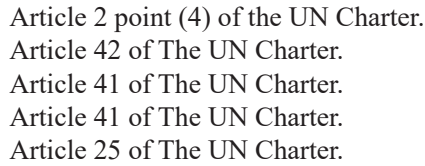


United Nations in a conflict is that for enforcing the law against the breach of international law by way of mentioning what kind of violation that has been committed. Sometimes, the conflicting parties claim themselves that they did not breach any international law since they committed such violation in order to use right of self-defense. If there are no decisions of the Security Council which oblige the states to do something, thus such state is still be able to claim its neutral status.

The provision governed under the UN Charter are accommodated by San Remo Manual 1994. Paragraph 7 stated that if the Security Council declares that the conflicting parties as parties who are responsible for any breach of international law, so the neutral state is not allowed to provide any helps except humanitarian assistance to such conflicting parties. ${ }^{22}$ The member states can provide aid to any states that become the victims of the breach of international law or the victims of aggression committed by the conflicting states.

Paragraph 7 of San Remo Manual 1994 is an implementation of Article 39 of the UN Charter, ${ }^{23}$ that if there is a threat or any breach of world peace or there is an aggression committed by a state, so the Security Council will decide which measures will be undertaken for restoring the world peace and security. The measure undertaken by the Security Council that is economics sanction or termination of diplomatic relations ${ }^{24}$ or using military armed forces, either land-force, naval or air force of the member states. ${ }^{25}$

The decision made by the Security Council binds to all the member states based on article $25 .^{26}$ The state which is not involved in conflict, or a neutral state, is subjected to the principle of neutrality that it is not allowed to provide aids to the state who is responsible for the breach of international law. However, the member states can provide assistance to the states who becomes the victim without breaching the principle of neutrality. ${ }^{27}$ For the states who are not the member states of the UN, the authority of the Security Council can be carried out based on Article 2 point (6), stated that the non-member states act based on the applicable principles, for the sake of world peace and international security. ${ }^{28}$ Paragraph $8{ }^{29}$ San Remo Manual 1994 asserted that the member states of the UN cannot make the principle of neutrality as a legal basis for acting which is not in line with the UN Charter or the decision of the Security Council. It means that the obligation of neutral state for not involving in an armed conflict has been breached. The member states of the UN have to prioritize their obligations for obeying the decision of the Security Council, rather than their obligation as a neutral state. The obligation for prioritizing the UN Charter compare to other international conventions regulated under Article 103. ${ }^{30}$

Paragraph 9 of San Remo Manual 1994 ${ }^{31}$ affirmed that the International Humanitarian Law is still applicable in every conflict with the intervention of the UN Security Council. The implementation of humanitarian law for the UN troops which sent to the conflict area governed under Convention on the Safety of United Nations and Associated Personnel signed in New York, 9 December 1994. Article 21 of the Convention stated that with regards to the protection operation of The UN and personnel or the responsibility of personnel, thus the International

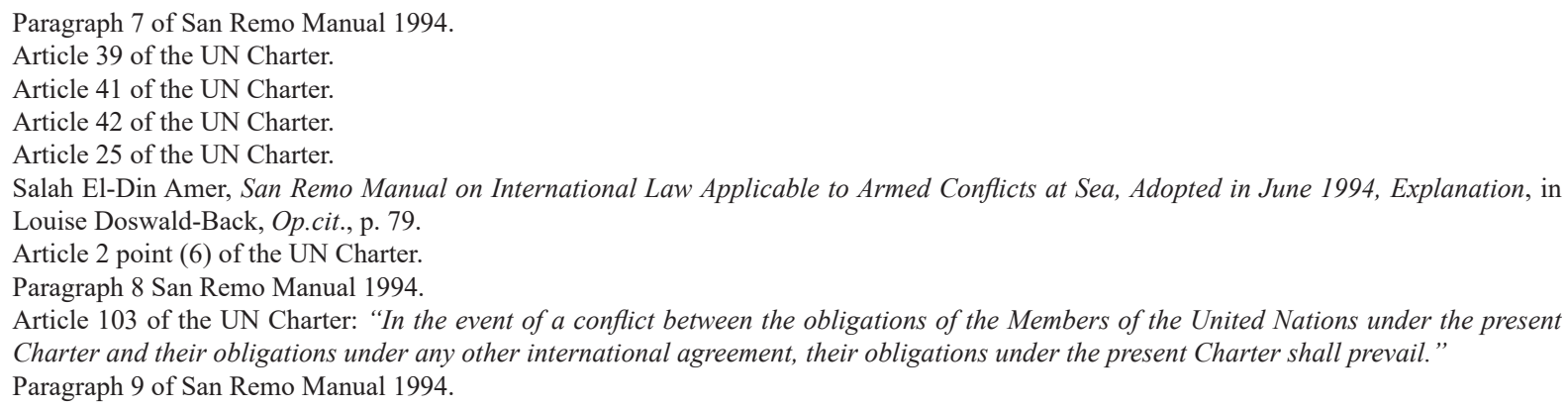


Humanitarian Law and human rights should be universally applied and respected. ${ }^{32}$

Besides the The UN Safety Convention and Associated Personnel 1994, the application of International Humanitarian Law is reflected under United Nations Secretary General's Bulletin (ST/ SGB/1999/13), on 6 August 1999. This Bulletin contains rights and obligations of the Peaceenforcement troops, method, and means of war that can be used, the principle of distinction, the protection towards civilians and others. Chapter I of the Bulletin asserts that the basic principles and rules of International Humanitarian Law is applicable for the UN troops when in armed conflict, in which such troops is involved actively as combatants. ${ }^{33}$

\section{The Principle of Neutrality at Sea According to San Remo Manual 1994}

Apart from such uncertainty, there is an agreement between states that an armed conflict at sea obliges to protect the states which is not taking part in such conflict, including the citizens of the states that is not involved and the aircraft and naval vessels that operates under the flag of neutral states. The rules of neutrality at sea does not only cover the rules regarding the orders and prohibitions that should be obeyed by the conflicting parties, however, most of it contains the obligations that must be obeyed by states which is not involved in such conflict as well as their citizens. Besides, the other aims form the neutrality principle at sea is to prevent expansion and escalation of an armed conflict.

Neutrality at sea experiences the important development after the adoption of UNCLOS 1982, particularly regarding the warfare area at sea. Some issues which affect the implementation of neutrality principle at sea in relation with the development of the rules of law of International law of the sea as reflected under UNCLOS 1982 covers: (1) the expansion of territorial of the sea becomes 12 miles; (2) there is Exclusive Economic Zone; and (3) the concept of archipelagic state. ${ }^{34}$

The newest rules of the principle of neutrality at sea governed under San Remo Manual 1994 adopting the traditional doctrines and principles, especially regarding with the relationship of conflicting parties and neutral states, and adjusted with the new rules of international law of the sea, particularly UNCLOS 1982 . This is because UNCLOS 1982 only governs about the use of sea when it is in a peace condition and the UNCLOS' provision is more developed compare to the previous era. The rules of law of the sea in the previous time, only distinguished the territorial of the sea including the inland waters and high sea. Whereas, nowadays, the sea that is subjected to the state's sovereignty is not only high sea and territorial sea but also including strait which was used to be meant for international cruise, for states that adjacent with straits and archipelagic water for archipelago.

Article 14 of San Remo Manual 1994 stated that: "Neutral waters consist of the internal waters, territorial sea, and, where applicable, the archipelagic waters, of neutral States. ${ }^{35}$ Neutral airspace consists of the airspace over neutral waters and the land territory of neutral States." This paragraph reflects 2 things. First, before UNCLOS 1982, the basic thing that was generally recognized regarding the neutral States is the wide of territorial sea for 3 miles measured from base line. The subsequent development is that the territorial sea becomes 12 miles and it is often measured using

32 Article 21 of Convention on the Safety of United Nations and Associated Personnel, 9 Desember 1994: "Nothing in this Convention shall affect: (a) The applicability of international humanitarian law and universally recognized standards of human rights as contained in international instruments in relation to the protection of United Nations operations and United Nations and associated personnel or the responsibility of such personnel to respect such law and standards; ....".

33 Section 1 United Nations Secretary General's Bulletin (ST/SGB/1999/13), on 6 August1999 stated that: "The fundamental principles and rules of international humanitarian law set out in the present bulletin are applicable to United Nations forces when in situations of armed conflict they are actively engaged therein as combatants, to the extent and for the duration of their engagement. They are accordingly applicable in enforcement actions, or in peacekeeping operations when the use of force is permitted in self-defence."

34 Bruce A. Harlow, “The Law of Neutrality at Sea for the 80's and Beyond”, Pacific Basin Law Journal, Vol. 3, No. 1-2, 1984 , p. 42.

35 Article 14 of San Remo Manual 1994. 
straight baseline. In the time when The Hague Conventions 1907 were still applicable, the States only recognized normal baseline. ${ }^{36}$ Second, the recognition of archipelagic states concept. By the existence of the archipelagic states concept, the seas among the archipelagic states, was a part of high seas, became territorial waters subjected to archipelagic states' sovereignty and called as archipelagic waters the expansion of territorial sea of state becomes 12 miles, yet both states remained treating the two zones like in the time when it was traditionally governed and before the applicability of UNCLOS 1982. ${ }^{37}$ However, under its development, those states received the status of archipelagic water which is the same with the territorial sea and the wide of territorial sea 12 miles.

The following are the important issues in the principle of neutrality at sea according to San Remo Manual 1994:

\section{a. The Prohibition from Hostile Actions at Neutral Territorial Water}

The first obligation that must be obeyed by conflicting parties towards the neutral territorial water is that inland waters and territorial sea, including the archipelagic water and straits which used for international cruise, are not allowed to conduct hostile actions. On the other hands, the neutral states is obliged to take measures for preventing the breach of the principle of neutrality committed by the conflicting parties, as mentioned under Article 15 of San Remo Manual 1994..$^{38}$ This paragraph aims for Indonesia as the biggest archipelagic state, stated that the archipelagic state is a neutral party. In the discussion of experts, it was said that:

$[\ldots]$ the first sentence of this paragraph centered primarily on whether it was reasonable, in view of the large expanse of archipelagic waters of some States (Indonesia being the prime example), to treat archipelagic waters in the same way as the territorial sea for the purpose of excluding belligerent hostile actions when the archipelagic State was a neutral. ${ }^{39}$

The basic principles were adopted from The Hague Convention XII 1907 that is regulated under Article $1^{40}$ and Article 25. ${ }^{41}$ Such Article stated that the conflicting parties have to respect the rights of sovereignty ${ }^{42}$ of neutral power. The neutral states oblige to supervise its area as well as its harbor in order to prevent the breach of law.

Hostile actions explained under paragraph 16 of San Remo manual 1994, are as follow: 43

a. Attack on or capture or objects located in, on or over neutral waters territory;

b. Use as a base of operations, including attack on or capture of persons or objects located outside neutral waters, if the attack or seizure is conducted by belligerent forces located in, on or over neutral waters;

c. Laying of mines; or

d. Visit, search, diversion, or capture.

36 The determination of normal baseline follows the shape of island, whereas straight baseline does not follow the natural shape of island, but drawn a straight line from two basepoints made by the coastal states.

37 Salah El-Din Amer, San Remo Manual on International Law Applicable to Armed Conflicts at Sea, Adopted in June 1994, Explanation, in Louise Doswald-Back, Op. cit., p. 94.

38 See Paragraph 15 of San Remo Manual 1994

39 Salah El-Din Amer, San Remo Manual on International Law Applicable to Armed Conflicts at Sea, Adopted in June 1994, Explanation, in Louise Doswald-Back, Op.cit., p. 95.

Article 1 of the Hague Convention XIII 1907.

Article 25 of the Hague Convention XIII 1907

42 Article 1 of the Hague Convention XIII 1907 stated that the rights of sovereignty of neutral states (soeverign rights of neutral power) however it refers to the sovereignty not sovereign right as regulated under Article 56 UNCLOS 1982 concerning the sovereignty of coastal state towards the natural resources in Exclusive Economic Zone.

43 Paragraph 16 of San Remo Manual 1994 
Such provision was adopted from some articles of The Hague Convention XIII 1907, Article $2,{ }^{44} 4,{ }^{45}$ and $5 .{ }^{46}$ Such articles governed about the prohibition from hostile actions, investigation, search, and capture; as well as the prohibition from justice action for seizure goods in neutral power; and regulates about the prohibition on using the area of neutral power as an operation base for the conflicting parties.

Some issues governed under Paragraph 16 of San Remo Manual 1994 is only a part of prohibited hostile criteria in territorial waters of neutral power. This can be seen from the use of words inter alia. Therefore, this paragraph is not perfect in regulating the hostile actions which prohibited for the conflicting parties and can be interpreted partially by the neutral state. ${ }^{47}$

\section{b. The prohibition from Using Territorial Water of Neutral Powers as a Sanctuary}

Besides prohibited from conducting hostile actions, the conflicting parties is also prohibited for using the territorial water of neutral state as a sanctuary. ${ }^{48}$ This regulation is a new issue governed under San Remo Manual 1994, yet there are some provisions contained under The Hague Convention XIII 1907 indirectly has determined that the territorial of neutral water is prohibited to be used as a sanctuary. It contains under article 14, 17, 18, 19 and $20 .{ }^{49}$ These articles govern about the activities of vessels war of the conflicting parties in neural state's harbor. Those articles are related to other obligations which have to be respected by the vessels of conflicting parties besides the prohibition from using the territorial water of neutral power as a sanctuary.

Article $14^{50}$ governs concerning the time limit for the vessels of conflicting parties for anchoring in neutral power's harbor. In such article indeed there is no certain limit of time regarding how long the vessel war can anchor, it is only said that right after the cancellation can be solved, the vessel war as soon as possible leaves the harbor of neutral power. This provision with regards to such extension is not applicable for the vessel who has a special mission for religion, scientific research, and humanity mission.

Article $17^{51}$ The Hague Convention XIII 1907 regulates about the limitation of repairing the vessel, it is only allowed as long as the vessel can cruise back and it is not allowed for putting back or enhancing its combating power. The neutral power has the right to determine what kind of repair should be done. Article $18^{52}$ governs about the prohibition on using neutral territorial water (harbor, either the entrance of harbor or territorial sea) for reloading goods or war tools and guns or adding personnel. Article $19^{53}$ and $20^{54}$ governs about the limit of reloading the logistics and fuel. Reloading logistics is allowed only for keeping the vessel can reach to the closest harbor in

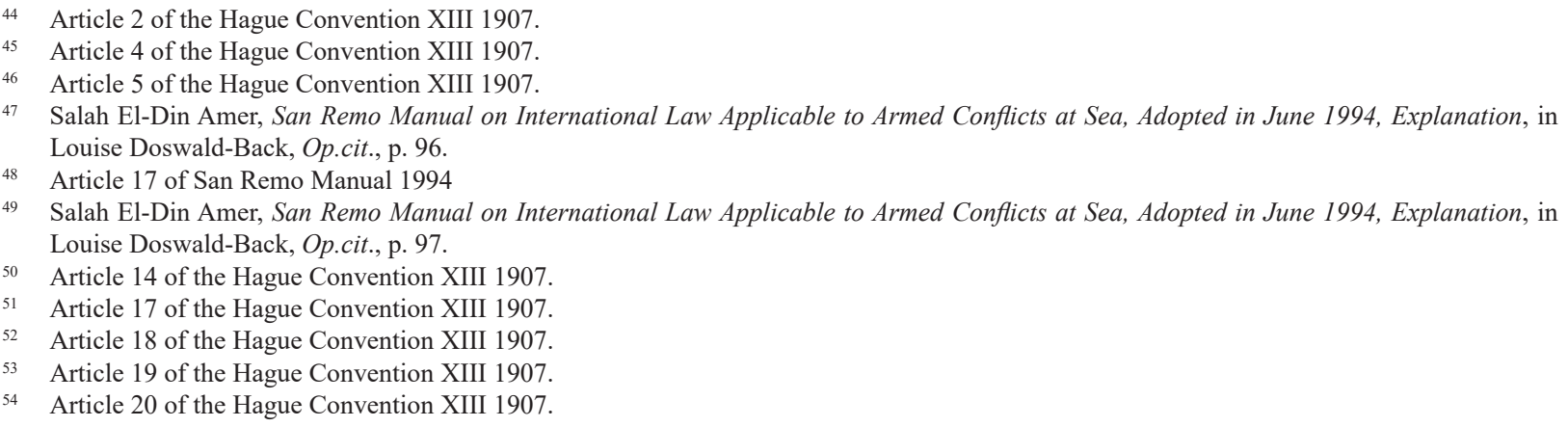


their own area. Besides, the vessel war of the parties is not allowed to reload the stuffs anymore for 3 (three) months in the same harbor of neutral state.

c. The Obligation of Undertaking Measures for Preventing and Stopping the Breach of Neutrality Conducted by the Conflicting Parties San Remo Manual 1994, Paragraph 22 stated that:

Should a belligerent State be in violation of the regime of neutral waters, as set out in this document, the neutral State is under an obligation to take the measures necessary to terminate the violation. If the neutral State fails to terminate the violation of its neutral waters by a belligerent, the opposing belligerent must so notify the neutral State and give that neutral State a reasonable time to terminate the violation by the belligerent. If the violation of the neutrality of the State by the belligerent constitutes a serious and immediate threat to the security of the opposing belligerent and the violation is not terminated, then that belligerent may, in the absence of any feasible and timely alternative, use such force as is strictly necessary to respond to the threat posed by the violation.

Based on this paragraph, the neutral state obliges to gather all its abilities to stop the breach committed by the conflicting parties in its territorial. If the neutral state is not willing or is not able to force its obligations as neutral power in hostile actions committed by the conflicting parties in neutral territorial, the other conflicting party (the enemy) can use their power if it is necessary in neutral territory, for protecting their own power as well as stopping the breach of law in neutral territory.

The first provision concerning this issue is under Article $8^{55}$ of the Hague Convention XIII 1907 which stated that the neutral power is obliged to gather all the means of power as the last resort for preventing the violation of law or set all the vessel armed in its legal territory in which there is a convincing reason that a vessel tends to cruise or involve in hostile operation against the neutral power. It is obliged to show the same efforts for hampering the vessel out from its jurisdictional territory for the vessel which tends to cruise or involve in hostile actions in which it is ordered to use all the powers and abilities or part of their jurisdiction for warfare.

Regarding the use of armed force, it can be said that the neutral state is obliged to use all the possible efforts and means for preventing incursion attack or attack from the air force of the conflicting parties in their jurisdiction and for preventing, in all the possible sense, for every violation of neutrality principle in their territory. However, it did not discuss about the possible consequences if the neutral states failed to fulfill its obligations. The conduct of conflicting parties is not allowed to be used for violating the integrity of neutral state, but for facing the enemy and there must be a reasonable excuse like state necessity or self-defense. Particularly, it is said that the conflicting parties are allowed to respond with violence only if the breach committed by the enemy leads to serious threats and direct and after the neutral state has record of such breach and there is a chance to end the threat.

d. The Existence of Warships of the Conflicting Parties at Ports and The Territorial Sea of Neutral Power

Neutral State can impose requirements, limitations, or prohibitions for entering the port, the flow of port or territorial water 
of neutral powers towards the war vessels of the conflicting parties or their captured vessels, and has to be fair towards the two parties. Paragraph 19 of San Remo Manual 1994 said that: "Subject to paragraphs 29 and 33, a neutral State may, on a nondiscriminatory basis, condition, restrict or prohibit the entrance to or passage through its neutral waters by belligerent warships and auxiliary vessels". This paragraph requires that the neutral state should apply based on the condition, limitation, and prohibition for the conflicting parties for entering the harbor, terminal or territorial water to all the conflicting parties without exception.

The provision above constitutes the reformulation of Article 9 of The Hague Convention XII 1907 which stated that the neutral state has to implement it fairly to both conflicting parties with regards to the requirements, limitation or prohibitions produced by the neutral State for entering the harbor, the flow of the harbor or territorial water of neutral state towards the warships of the conflicting parties or their captured vessels. At least, the neutral State is able to prohibit the vessels of conflicting parties for entering the harbor or the flow of the harbor which was failed or not obeying the orders as well as the rules produced by the neutral State.

The neutral state can permit some actions which are considered to be lawful conducted by the conflicting parties in its neural territory as stated in paragraph 20 of San Remo Manual 1994:56

1. Passage through its territorial sea, and where applicable its archipelagic waters, by warships, auxiliary vessels and prizes of belligerent States; warships, auxiliary vessels and prizes may employ pilots of the neutral State during passage;

2. Replenishment by a belligerent warship or auxiliary vessel of its food, water and fuel sufficient to reach a port in its own territory; and

3. Repairs of belligerent warships or auxiliary vessels found necessary by the neutral State to make them seaworthy; such repairs may not restore or increase their fighting strength.

Paragraph 20 cannot be separated from paragraph 19. Paragraph 19 of San Remo Manual 1994 provides sovereignty to neutral State according to condition, for limiting or prohibiting passage through neutral waters, whereas paragraph 20 governs about the neutral States can permit actions conducted by the warships, water transportation, and its seized goods without jeopardizing its neutrality. The measures which undertaken by the neutral States, either in determining limitation or permitting something for warships of both parties, have to be equally implemented towards both conflicting parties without exception with taking into account the obligation of impartiality and nondiscrimination.

Paragraph 20 (a) governs regarding the permission of the conflicting parties' warships for using official signs during traversing territorial sea and archipelagic water for archipelagic state. This provision adopts from Article $11^{57}$ of the Hague Convention XIII 1907 which stated that the neutral state allows the conflicting parties' warships for using the official signs of harbor, and Article $23^{58}$ of the Hague Convention XIII 1907 
allows prizes enter into ports. If it compares with Paragraph 20 (a), thus San Remo Manual 1994 has made the more limited provision than the one that has governed under The Hague Convention 1907, since San Remo Manual 1994 only allows prizes (plunder ships) for traversing the territorial sea and archipelagic water without entering the ports. ${ }^{59}$

Paragraph 20 (b) contains the provision of replenishment of conflicting parties' warships. Even though they are allowed to replenish foods and fuels, however the applicable law does not regulate clearly regarding the quantity or the amount. Practically, such issues depend on the neutral State in determining the requirements of such replenishment with taking into account the principle of non-discrimination and the prohibition from using the neutral power's territory for its own interest.

The same provision can be found in The Hague Convention XIII 1907 Article 19. ${ }^{60}$ However, the Hague Convention provides more rigid details with regards to replenishment. It does not only regulate the replenishment of foods, water and fuels, but also prohibiting from adding armament or artillery or strengthen the communication network or adding communication tools with military powers of the conflicting parties, as provisioned under Article $6^{61}$ and $18 .^{62}$

Article 20 (c) of San Remo Manual sets regarding the ship repair. The ship repair is allowed if only for making the ship can back to normal condition and cruising normally (seaworthy) and that is not for enhancing or strengthening its power of combat. This stipulation is a statement which has been set under Article $17^{63}$ of the Hague Convention XIII 1907. This regulation can be found either in The Hague Convention XIII 1907 or San Remo Manual 1904 is unequivocally concerning what kind of repair can be done towards the damage as a result of war, although it is only for seaworthy as it has been required. However, in any situation, the warships of both parties who undertake ship repair, is not allowed to add or repair its system of artillery or strengthening from any aspect for its combat performance. It is an obligation of neutral power for determining what kind of repair that is needed for making it seaworthy and asserting that their level of abilities in finishing the repair.

The presence of warships at ports, the flow of ports or the territorial waters of neutral power cannot be more than 24 hours, unless bad weather or damage so that the warship is not able to cruise/not fulfilling the seaworthiness or the warships has a special mission such as religious mission, scientific research and humanity mission. San Remo Manual Paragraph 21 stated that:

A belligerent warship or auxiliary vessel may not extend the duration of its passage through neutral waters, or its presence in those waters for replenishment or repair, for longer than 24 hours unless unavoidable on account of damage or the stress of weather. The foregoing rule does not apply in international straits and waters in which the right of archipelagic sea lanes passage is exercised.

The regulation of paragraph 21 is a reregulation of article $12 .{ }^{64}$ The Hague Convention XIII 1907 stated that the absence of special provision which is contradictory

\footnotetext{
Explanation San Remo Manual 1994, Op cit., p. 100.

Article 19 of the Hague Convention XIII 1907.

Article 6 of the Hague Convention XIII 1907.

Article 18 of the Hague Convention XIII 1907.

Article 17 of the Hague Convention XIII 1907.

Article 12 of the Hague Convention XIII 1907.
} 
with the neutral states' law, the warships of the conflicting parties are not allowed to stay at the port, roadsteads, or territorial water of neutral power more than 24 hours unless there are some problems governed under the Convention;

Besides article 12, article $13^{65}$ the Hague Convention XIII 1907 stated that if a state is not being notified regarding the conflict then seeing a warship of the conflicting party in one of the port or roadstead or in their territorial sea, must notify the warships of conflicting parties for departing within 24 hours or according to time zone of such area; Article $14^{66}$ is also an article which inspired the formation of paragraph 21 of San Remo Manual 1994.

If the conflicting parties commits the breach of neutral water regime, as set under this document, the neutral power obliges undertaking necessary measures for discontinuing such violation. If the neutral state fails stopping the violation in their territory committed by one of the conflicting parties, thus the other conflicting party has to warn the neutral power and providing reasonable times for neutral powers for keeping to stop the breach of neutrality committed by the conflicting parties. If the breach of neutrality incurs a sudden and serious threat for the security of the enemy and the breach is unstoppable, therefore the conflicting party, without acknowledgement and as soon as possible, allows to use their necessary force directly in order to respond the threat occurred from the breach of neutrality. ${ }^{67}$

\section{e. The Rights of Transit Passage for Foreign Vessels}

An armed conflict at sea, the ships of belligerent has the right to across the territorial sea of the neutral powers, and vice versa, the ships of neutral states have the right to traverse the territorial sea of belligerents. The regulation concerning the rights of transit passage for foreign vessels during an armed conflict has experienced an important development by the presence of the expansion of territorial coastal state becomes 12 miles and the recognition of archipelagic state. Before the presence of UNCLOS 1982, the states only recognize the rights of transit passage at territorial sea, so that after UNCLOS 1982 there are two rights of transit passage which can be used by foreign vessels, that is the rights of transit passage at straits which is used for international cruise and rights of roadsteads of archipelago at archipelagic state. This change also brings the effect in implementing the rights of transit passage during an armed conflict. San Remo Manual 1994 provides regulations which contain some principles that can be used during an armed conflict at sea. The principles of the implementation on the rights of transit passage for foreign vessel are as follows:

First, the warship, multipurpose of water transportation, military air craft and multipurpose aircraft all the states has the right to implement the rights of peaceful transit, the rights of transit passage and the rights of transit of archipelagic sea lanes passage. Such rights are applicable for all states, either belligerents or neutral states. This provision is found under paragraph 23 and 26 of San Remo Manual 1994. ${ }^{68}$ It is further elaborated under paragraph $28^{69}$ which stated that all ships, either warship of belligerents or neutral states have the rights

\footnotetext{
Article 13 of the Hague Convention XIII 1907.

Article 14 of the Hague Convention XIII 1907.

Paragraph 22 of San Remo Manual 1994.

Paragraph 23 and 26 of San Remo Manual 1994.

Paragraph 28 of San Remo Manual 1994.
} 
to enjoy the rights of transit passage and rights archipelagic sea lanes passage.

Second, the right of transit passage is applicable during the peaceful condition and during armed conflict in accordance with the international law, as set under paragraph 27 of San Remo Manual $1994 .{ }^{70}$ This provision asserts that the right of transit passage and the right of archipelagic sea lanes passage during the peaceful condition is still applicable during an armed conflict. What regulated under peaceful condition is based on UNCLOS 1982 is still applicable mutatis mutandis during an armed conflict, including the obligation of strait states and archipelagic state.

Third, the neutral state, covers territorial sea, straits in which is used for international cruise for straits state and archipelagic sea is prohibited to be threaten by the implementation of the rights of transit passage for foreign vessels. This is set under paragraph 24 and 25 of San Remo Manual 1994. ${ }^{71}$ It is further explained under paragraph $30 .{ }^{72}$ Fourth, the neutral power is not allowed to suspend, hamper, or impede the right of transit passage of foreign vessels, as governed under paragraph 29 of San Remo Manual 1994. ${ }^{73}$

Fifth, the recognition of the right of transit passage for warships and multipurpose ships at straits which is used for international cruise and archipelagic sea, either in conflicting territory or in neutral territory, as stipulated under paragraph 31,32 and 33. Paragraph 31 stated that: "In addition to the exercise of the rights of transit and archipelagic sea lanes passage, belligerent warships and auxiliary vessels may, subject to paragraphs 19and 21, exercise the right of innocent passage through neutral international straits and archipelagic waters in accordance with general international law." Further, paragraph 32 set that: "Neutral vessels may likewise exercise the right of innocent passage through belligerent international straits and archipelagic waters." Then paragraph 33 stipulated that: "The right of non-suspendable innocent passage ascribed to certain international straits by international law may not be suspended in time of armed conflict."

Besides in territorial sea, the right of transit passage for foreign vessel, can be undertaken in straits which is used for international cruise and at the archipelagic sea. The right of transit passage is applicable for warships and multipurpose of water transportation. Military aircraft and multipurpose aircraft do not have any rights for transiting at peace. The right of transit at peace is only applicable for warships and any multipurpose water transportation of the belligerents in neutral waters, and vice versa, the right of transit passage at peace is applicable for neutral ships in belligerent's waters. The right of transit passage at peace at straits is subjected to article 45 of UNCLOS 1982 remains to be recognized.

\section{Conclusion}

The implementation of neutrality at sea has experienced reformation through times, affected by the development of international law in general. However, the development did not come with legal certainty. Up until now, the provision of neutrality principle at sea according to San Remo Manual 1994. Even though in the form of Manual, San Remo Manual 1994 has an important value in replenishing the legal vacuum of the neutrality principle. 
The development of the provision of neutrality principle at sea is due to the presence of Chapter VII of UN Charter. By the existence of the obligation for state which has to implement the decision of The UN Security Council in a humanitarian intervention, thus such issue contradicts with the principle of neutrality which stated that the neutral powers may not be interfered and the neutral state must be impartial, which means that they cannot be involved in a warfare. Other development is that, under the provision of neutrality principle is due to the presence of UNCLOS 1982. San Remo Manual 1994 has imposed UNCLOS 1982 by mutatis mutandis in an armed conflict. Particularly in implementing the right of transit passage for foreign vessel, the provisions under San Remo Manual 1994 contradicts with the sovereignty of neutral powers.

\section{REFERENCES}

\section{A. Books}

Haryomataram, 2005, Pengantar Hukum Humaniter, RajaGrafindo Persada, Jakarta.

Marzuki, Peter Mahmud, Penelitian Hukum, Kencana Prenada Media Group, Jakarta, 2010.

Kalshoven, 2007, Reflections on the Law of War, Collected Essays, Martinus Nijhoff Publisher, London.

A.R. Thomas and James C. Duncan (Editors), 1999, Annotated Supplement to The Commander's Handbook on the Law of Naval Operations, Newport RI, Newport.

\section{B. Journal Articles}

Harlow, Bruce A., "The Law of Neutrality at Sea for the 80's and Beyond", Pacific Basin Law Journal, Vol. 3, No. 1-2, 1984.

\section{Articles with Editor Antology}

Salah El-Din Amer, San Remo Manual on International Law Applicable to Armed Conflicts at Sea, Adopted in June 1994, Explanation, in Louise Doswald-Back, 1995, San Remo Manual on International Law Applicable to Armed Conflicts at Sea I prepared by international lawyer and naval experts convened by International Institute of Humanitarian Law, Cambridge University Press, Great Britain.

\section{Internet}

International Committee of The Red Cross, "Declaration Respecting Maritime Law Paris, 16April 1856", https://ihl-databases.icrc.org/ ihl/WebART/105-10001? OpenDocument, accessed 11 December 2016.

International Committee of the Red Cross, Treaties, State Parties, and Commentaries, https:// ihl-databases.icrc.org/ihl/WebART/10510001? OpenDocument, accessed on 31 August 2016.

\section{E. International Treaties}

Declaration Respecting Maritime Law, Paris, 30 March 1856, enter into force 16 April 1856.

Convention (XIII) concerning the Rights and Duties of Neutral Powers in Naval War, The Hague, 18 October 1907.

Convention on Maritime Neutrality, Havana, 20 February 1928.

United Nations Charter.

Statute of the International Court of Justice.

United Nations Convention on the Law of the Sea, 10 December 1982.

San Remo Manual on International Law Applicable to Armed Conflict at Sea, June 1994.

Convention on the Safety of United Nations and Associated Personnel, 9 December1994.

United Nations Secretary General's Bulletin (ST/ SGB/1999/13), 6 August 1999. 